YEARBOOK of ANTITRUST and REGULATORY STUDIES www.yars.wz.uw.edu.pl
Peer-reviewed scientific periodical, focusing on legal and economic issues of antitrust and regulation. Creative Commons Attribution-No Derivative Works 3.0 Poland License.

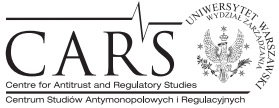

Centre for Antitrust and Regulatory Studies, University of Warsaw, Faculty of Management www.cars.wZ.uw.edu.pl

\title{
Development of the Judicial Review of the Decisions of the Antimonopoly Office of the Slovak Republic
}

\author{
by
}

Silvia Šramelová* and Andrea Šupáková**

\section{CONTENTS}

I. Introduction

II. General remarks

III. Application of the 'economic continuity test' as a mitigating circumstance

IV. Competences of the Slovak Antimonopoly Office in regulated sectors

V. Nullum crimen sine lege - application of the so-called 'general clause'

VI. Bank cartel judgment

VII. Infringement of a decision prohibiting a concentration

VIII. Conclusions

\section{Abstract}

The article provides an analysis of the most important judgments rendered by Slovak courts at the end of 2010, in the course of 2011 and at the beginning of 2012. The article focuses solely on judicial review of decisions issued by the National Competition Authority of the Slovak Republic.

Slovak courts dealt with several key issues concerning public enforcement of competition law such as: the application of the so-called 'general clause'; competences of the Slovak competition authority in regulated sectors; and the application of the economic continuity test. Some of the conclusions resulting from these judgments may be considered disputable. It may be argued, in particular, that they may jeopardize the effective enforcement of competition law in the Slovak

* Silvia Šamelová, lawyer, the Antimonopoly Office of the Slovak Republic, Legislative, Legal and European Affairs Division; postgraduate student, Pan-European University, Faculty of Law, Department of International Law and European Law.

** Andrea Šupáková, attorney, Law Office of DLMU, Bratislava. 
Republic. At the same time, the discussed jurisprudence has managed to clarify a number of key issues which had been subject to debate for a number of years. The article presents a review of these judgments, summarizes their key conclusions and considers their possible impact on the system of public enforcement of competition law in the Slovak Republic. The article is divided into a number of parts, each of which covers an individual case, the titles of which refers to the main topic that was under discussion in the presented judgment.

\section{Résumé}

Cet article analyse les décisions les plus importantes rendues par les cours slovaques en fin de l'année 2010, au cour de l'année 2011 et au debut de l'anneé 2012. Larticle traite exclusivement la révision judiciaire des décisions rendues par Bureau antimonopole de la République slovaque.

Les cours slovaques se sont penchées sur quelques questions clés relatif à l'application du droit de la concurrence tel que l'application de la clause générale, l'autorité de Bureau antimonopole de la République slovaque dans les secteurs régulés et l'application du test de la continuité économique.

Certains conclusions résultants de ces décisions peuvent être considérées comme litigieuses.

En particulier, il peut être soutenu que ces décisions peuvent affecter l'application effective du droit compétitif en République slovaque. Il est à noter que certains de ces décisions ont éclairé les questions qui ont été discutées pendant plusieurs années. Cette contribution donne un aperçu de ces susdites décisions, résume les principales conclusions découlant de ces décisions et analyse l'influence potentiel sur le système de l'application public du droit de la concurrence en République slovaque. La contribution est divisée en plusieurs parties, chacune d'entre elles consacrée à un cas particulier, les titres des articles sur des thèmes clés, qui se consacre à la décision.

Classifications and key words: economic continuity test; mitigating circumstance; competence; sectoral regulation; general clause; reduction of fine; unlawful operation on the market

\section{Introduction}

When it comes to the judicial review of its recent decisions, the Slovak competition authority - the Antimonopoly Office of the Slovak Republic (hereafter, the AMO) - has little reason to celebrate. The number of cases that it has lost before Slovak courts significantly exceeds the number of its decisions being upheld. 
Courts often either completely annul AMO's decisions or reduce the fine imposed therein to a symbolic amount only. There can be no doubt that the enforcement of competition cases in Slovakia has become harder in recent years. Courts often annul AMO's decisions merely with reference to procedural errors that occurred during the proceedings before the competition authority, without even beginning to deal with the merits of the case subject of the judicial review.

Considering the small number of court cases actually won by the AMO, years 2010-2012 do not differ substantially from earlier years. Nevertheless, a small amount of hope exists for the competition authority since the Supreme Court of the Slovak Republic, acting as the court of appeals for competition cases, reversed recently a number of first instance judgments that were adverse to the AMO upholding, in turn, the competition authority's original decisions.

The aim of this paper is to present the most interesting cases subject to judicial review at the end of 2010, in the year 2011 and at the beginning of 2012.

\section{General remarks}

It is worth starting the paper with a brief introduction of the system of judicial review of the decisions issued by the AMO - the National Competition Authority (hereafter, NCA) of the Slovak Republic. In Slovakia, the rules of judicial review of administrative decisions are set forth by the Act No. 99/1963 Coll. - the Civil Procedural Code as amended (hereafter, Civil Procedural Code), particularly in its part named 'Administrative justice'.

AMO decisions are taken on the basis of a 2-instance system. In the first instance, the executive body of the $\mathrm{AMO}^{1}$ issues a decision, which may be reviewed by the Council of the AMO. When a decision in a particular case is issued by the Council of the AMO and becomes final, the participants of the administrative proceedings have the right to bring the case before a court within 2 months from the day when the decision became final. The legal instrument used for that purpose is an action ${ }^{2}$ to be filed with the respective court within two months from the day when the last instance decision of the authority was delivered to the participant. The court that has the competence

1 Division of Agreements Restricting Competition, Division of Abuse of a Dominant Position or Division of Concentrations.

2 The action is admissible only under the proviso that a party to a proceedings before the AMO appealed the decision of the executive body of the AMO to the Council of the AMO.

VOL. 2012, 5(7) 
to review the decision of the AMO is the Regional Court in Bratislava, acting as the court of first instance in matters of competition law.

If the court decides that the contested decision and the preceding administrative procedures comply with the law, the court renders a judgment dismissing the action. If it rules against the appealed decision, it reverses the AMO decision and refers the case back to the competition authority for renewed assessment. Together with the decision of the Council of the AMO, the court may reverse also the first instance decision. Since 2002, the court has also the right to change the amount of the fine imposed by the AMO. Unsatisfied parties, usually both the claimant and the AMO, can appeal the judgment of the Regional Court.

The Supreme Court of the Slovak Republic reviews the judgment of the Regional Court acting in this respect as the court of appeals for competition law cases. The Supreme Court may reverse, affirm, or change the judgment of the court of first instance.

Even after the judgement of the Supreme Court becomes final, the party to the judicial proceeding may lodge a complaint to the Constitutional Court of the Slovak Republic, when it assumes, that the court breached its fundamental rights or freedoms during the foregoing judicial proceedings. In case the complaint of the complainant is justified, the Constitutional Court annuls the faulty judgement and refers the case back to the court, that issued the respective judgement.

\section{Application of the 'economic continuity test' as a mitigating circumstance}

The judgment of the Supreme Court of the Slovak Republic concerning the abuse of a dominant position by the Railway Company Cargo, a.s. (hereafter, Cargo), case no. 1 Sžhpú/1/2011 3

The Cargo proceedings are historically the first case where the European Commission submitted to Slovak courts its written observations to a competition law case under Article 15 (3) of Regulation 1/20034.

\footnotetext{
3 The judgment of the Supreme Court of the Slovak Republic of 31 January 2012.

4 Council Regulation (EC) No. 1/2003 of 16 December 2002 on the implementation of the rules on competition laid down in Articles 81 and 82 of the Treaty, OJ [2003] L 1/1: 'Where the coherent application of Article 81 or Article 82 of the Treaty so requires, the Commission, acting on its own initiative, may submit written observations to courts of the Member States. With the permission of the court in question, it may also make oral observations'.
} 
In 2006, the AMO found that Cargo has abused its dominant position and imposed upon it a heavy fine in the amount of c. 2490000 Euro $^{5}$. Cargo is a company owned by the Slovak Republic. It carries out railway transport and business activities and, in particular, transport and carriage services of goods in rail-freight traffic. In respective time, Cargo provided a rail-freight transport of a large amount of cement on a number of routes, including the route Rohožník-Devínska Nová Ves state border to the company Holcim (Slovakia), a.s. (hereafter, Holcim). Holcim carried out business activities in a sector of producing and selling cement and other construction materials.

Holcim purchased rail-freight services from Cargo via three shipping companies. Cargo sold its services to shipping companies on the basis of consignments, which were concluded every year. The contracts included also agreements on prices. In terms of these agreements, Cargo provided its services to shipping companies for discounted prices compared to general tariffs, which otherwise applied.

The said abuse occurred when Holcim planned to purchase rail-freight services of cement on the route Rohožník-Devínska Nová Ves state border from the company LTE, a.s., instead of Cargo, because LTE's offer was more advantageous to Holcim. At that time, LTE, a.s. was a new entrant on the recently liberalised railway market, making it a competitor of Cargo. As a reaction to this situation, Cargo terminated its existing agreements on prices with two shipping companies providing rail-freight transport services to the company Holcim.

Because of the actions of the dominant entity (Cargo), shipping companies planned to increase the prices for the transport on all the routes covered by the contract between Cargo and Holcim an unfavourable development for Holcim. Consequently, Holcim terminated the planned cooperation with LTE and signed a contract on the provision of all its rail-freight transport services with Cargo. Hence, the dominant company effectively eliminated LTE from the relevant market for the provision of rail-freight transport of a large amount of cement on the route Rohožník- Devínska Nová Ves state border.

The anticompetitive behaviour of Cargo affected trade between EU Member States. Thus, the Slovak competition authority applied Article 82 of the EC Treaty (current Article 102 of the Treaty on the Functioning of the European Union, hereafter TFEU).

Cargo was established on 1 January 2005 as a result of the division of the former passenger and freight rail traffic operator - Železničná spoločnost', a.s. The former operator has been split into two legal successors: Zelezničná spoločnost', a.s. (for the supply of passenger transport services) and Cargo (for

5 Decision of the AMO Council no. 2006/DZ/R/2/144 issued on 22 December 2006 in conjunction with the decision of the AMO no. 2006/DZ/2/1/067 issued on 3 June 2006. 
the supply of services of rail-freight transport). Considering the timeframe of the infringement, part of the alleged anticompetitive behaviour took place before the legal separation of the two operators, while part occurred during the existence of Cargo.

The Slovak competition authority applied here the 'economic continuity test' under the criteria set out by the jurisprudence ${ }^{6}$ of the Court of Justice of the European Union. On this basis, Cargo was found responsible for the entire duration of the anticompetitive behaviour despite the fact that no provision of Slovak law explicitly enables the AMO to prosecute a successor company for the conduct of its predecessor ${ }^{7}$.

The Regional Court in Bratislava reviewed the decision issued by the AMO and decided to substantially reduce the fine originally imposed on Cargo (from 2490000 to c. 299000 Euro $^{8}$ ). The Court confirmed the accuracy of the AMO's use of the economic continuity test despite the lack of a clear legal basis for doing so. The Court stressed in particular that Cargo took over both material and legal assets of its predecessor and continued with the performance of the same economic activities.

Nevertheless, the Court decided to substantially reduce the fine. Above all, it referred to the fact that the sanction in this case did not fulfil a preventive function; the Court said that the AMO should have considered the fact that Cargo did not, in fact, participate in the illegal conduct for the whole duration of the abuse. The Court said, in essence, that it was necessary to consider the application of the economic continuity test as a quasi-mitigating circumstance in this case.

The conclusion reached by the first instance court is rather controversial. Does it mean that an undertaking can avoid responsibility or punishment by virtue of a mere structural change?

The AMO appealed the judgment to the Supreme Court of the Slovak Republic which changed the judgment of the Regional Court in Bratislava completely dismissing Cargo's original appeal.

${ }^{6}$ According to EU jurisprudence, conditions to be met in this case are: 1) the new company continues the activity of the entity that has committed a violation, i.e. continuity of the economic activities of these two companies exists, and, 2) the original entity has ceased to exist. See judgments: joined cases 40-48, 50, 54-56, 111,113 and 114-73 Cooperatieve Vereniging Suiker unie UA (SU) and others $v$ Commission, ECR [1975] 1163; joined cases 29/83 and 30/83 Compagnie Royale Asturienne des Mines SA and Rheizink GmbHv Commission, ECR [1984] 1679; C-49/92 P Commission v Anic Partecipazioni SpA, ECR [1999] I-4125; joined cases C-204/00 P, C-211/00 P, C-217/00 P and C-219/00 P Aalborg Portland A/S and others $v$ Commission, ECR [2004] I-00123.

7 The AMO followed the concept whereby undertakings cannot escape antitrust liability under national company law by simply restructuring, see e.g. Van bael \& Bellis, Competition law of the European Community, Hague 2005, p. 39.

8 Case no. 1 S 27/2007, judgment of 6 December 2007. 
Cargo was the first case where the European Commission submitted to a Slovak court its written observations on the applicability of Articles 101 and 102 TFEU. The Commission pointed out that the economic continuity test should be applied equally in all EU Member States. The effective use of this concept does not only translate into the finding of a successor's responsibility for the activities of its predecessor, but also the ascertainment of its responsibility in extenso. The Commission noted also that there was a strong link between finding responsibility and imposing a fine and stated that the consideration of the application of the economic continuity test as the mitigating circumstance would render the application of EU competition rules effective.

The Slovak Supreme Court referred first to the jurisprudence of the Court of Justice of the EU regarding the nature and function of the economic continuity test. Surprisingly, it refused to deal with the statements and pleas submitted by Cargo in its reaction to AMO's appeal (including pleas impugning the responsibility of Cargo for the illegal conduct, the liquidating character of the fine imposed etc.). The Supreme Court referred to the Roman law principle vigilantibus iura scripta sunt. It pointed out that since Cargo did not appeal the decision of the Regional Court in Bratislava, it acknowledged its responsibility for the anticompetitive behaviour at hand. The Supreme Court suggested also that by decreasing the fine imposed, the Regional Court usurped for itself the competences of the administrative body. The first instance court did so, despite the fact that it did not properly reason its conclusions and did not present any new evidence with regard to its possible doubts.

The Supreme Court referred to the jurisprudence of the Court of Justice of the EU in the case C-150/94 United Kingdom v the Council of the European Union $^{9}$ where it was stated that: 'the Court cannot substitute its assessment for that of the Council as to the appropriateness or otherwise of the measures adopted, if those measures have not been shown to be manifestly inappropriate for achieving the objective pursued'.

The Slovak Supreme Court concluded that neither the principle of legitimate expectations, nor the principle of equal treatment, was breached by the AMO in its administrative proceeding. It pointed out that the competition authority respected the limits set upon it by both Slovak and EU law and thus there was no reason to impugn the discretion of the administrative body. According to the Supreme Court, courts should not review the accuracy of the discretionary powers awarded to administrative bodies; it should review only the conformity of its discretion with the law.

\footnotetext{
9 ECR [1998] I-7235.
} 
With respect to the amount of the fine imposed, the Supreme Court did not agree with the opinion of the Regional Court in Bratislava whereby the AMO unreasonably stressed its repressive function. It emphasized that the aim of sanctions is both prevention and repression. According to the Supreme Court, these two functions of administrative fines cannot be separated.

All this notwithstanding, the Constitutional Court of the Slovak Republic reversed in 2011 the said judgment of the Supreme Court ${ }^{10}$ due to procedural mistakes that were committed by the Supreme Court. The subsequent judgment of the Supreme Court issued in January 2012 constrains, however, the same wording as its earlier ruling in this case. ${ }^{11}$

This case shows how the cooperation between national courts and the Commission may help in judicial reviews of competition law decisions, especially in new Member States, where the courts do not have sufficient experience with the application of EU competition law.

\section{Competences of the Slovak Antimonopoly Office in regulated sectors}

The judgment of the Supreme Court of the Slovak Republic in case eustream, a.s. (hereafter, eustream) $)^{12}$, case no. 4Sžh 1/2010

This case concerned the judicial review of an AMO decisions ${ }^{13}$ concerning the abuse of a dominant position committed by eustream on the relevant market for the provision of connection services to the natural gas transmission network. The scrutinised abuse took the form of the use by eustream of an unfair trading condition. According to the AMO, eustream made connecting a distributional company to its transmission network conditional upon the sale of the connecting facility. The said abuse occurred when eustream and the distributional company negotiated a contract of connecting a distributional network of a distributional company to a transmission network. In order to connect to the transmission network, the distributional company built up a connecting facility on its own expenses. At the end of the negotiating process,

10 Judgment of the Constitutional Court of the Slovak Republic of 14 June 2011, case no. III. ÚS 170/2011-46.

11 Judgment of the Supreme Court of the Slovak Republic of 31 January 2012, case no. $1 /$ Sžhpú1/2011.

12 Judgment of the Supreme Court of the Slovak Republic of 28 April 2011 in case no. 4Sžh1/2010.

13 Decision of the Council of the AMO no. 2008/DZ/R/2/076 of 26 Septmber 2008 in conjunction with the decision of the AMO no. 2007/DZ/2/1/105 of 14 December 2007. 
eustream laid the claim of the sale of the connecting facility. The distributional company accepted this condition in order to prevent damages that might have resulted from breaking its own contractual obligations in case the connection to the transmission network had not been realized.

In its judgment, the Regional Court in Bratislava dismissed the appeal action submitted by eustream and upheld the decision of the $\mathrm{AMO}^{14}$. One of the key issues discussed in the judgment was the NCA's competences in regulated sectors and the potential risk of breaching the ne bis in idem principle by the parallel exercise of the powers of the competition authority and sector-specific regulator (hereafter, National Regulatory Authority, NRA) ${ }^{15}$. The court stated that unless a NRA takes a particular action or a legal provision exists which enables it to punish an undertaking for certain unlawful behaviours, it is not possible to refuse the competences of the AMO in regulated sectors. The court apparently followed the concept whereby no anticompetitive behaviour should remain non-punishable. In other words, according to the first instance court, the competences of the AMO in regulated sectors would be excluded in cases when an appropriate sector-specific rule exists (provision of the law or a particular action of the regulator) that can be enforced by the relevant NRA.

The Supreme Court of the Slovak Republic took a different stance and changed the judgment of the Regional Court annulling at the same time the original decisions of the AMO. By doing so, it opened the discussion on the exercise of the powers of Slovak competition authority in regulated sectors. Nevertheless, the Supreme Court dealt with this issue in light of the facts of the case at hand making it difficult to draw general conclusions from the judgment. It is, however, possible to see that the Supreme Court's attitude towards the competences of the AMO was different to that shown by the first instance court. It is apparent, that the Supreme Court did not accept the interpretation of the Regional Court. It seems that according to the Supreme Court, it is sufficient to establish whether the law potentially enables a NRA to act in order to assess the existence of the AMO's competences in regulated sectors. In the opinion of the Supreme Court, the fact that market behaviour can be adjusted by a given NRA excludes the competences of the AMO in that regulated sector.

It is worth noting that the competition authority disagreed with the opinions of both courts, be it the judgment of the Regional Court or the ruling of the Supreme Court. However, the approach of the first instance court is somewhat more acceptable. It is important in this context to pay attention to the jurisprudence of the courts of the European Union. According to latest EU judgments, the competences to act of NCAs cannot be excluded unless a given

14 Judgment of the Regional Court in Bratislava of 30 June 2010 in case no. 2S/204/2008.

15 In Slovakia, it is the Regulatory Office For Network Industries. 
regulator had directly obliged an undertaking to engage in anticompetitive behaviour and the 'regulated' undertaking did not have any other possibility than to comply with the obligations set out by that NRA ${ }^{16}$.

It is indisputable that competition authorities and sector-specific regulators are both established to protect competition. However, unlike NCAs, the purpose of NRAs is the imposition of ex ante rules in areas where competition does not work properly. By contrast, competition authorities prosecute ex-post anticompetitive behaviour ${ }^{17}$. Both entities have at their disposal different legal instrument to exercise their powers. A NRA cannot, for instance, sanction the abuse of a dominant position or competition restricting agreements. Nevertheless, the scope of sector-specific regulation often closely resembles that of competition law, especially with respect to margin squeeze, predatory prices etc. However, the two set of rules only exceptionally overlap to an extent that would exclude the exercise of parallel competences of the given NRA and NCA.

Whilst the conclusion of the Regional Court concerning the question of the competences of the Slovak competition authority may be disputable to some extent, the conclusions of the Supreme Court are not sustainable at all. It is simply not possible to accept the opinion that sole subordination of a particular industry sector to the supervision of a regulator would totally exclude the competences of the competition authority in this field. Such an approach would seriously jeopardize the effectiveness of competition law enforcement in regulated sectors.

\section{Nullum crimen sine lege - application of the so-called 'general clause'}

The judgment of the Supreme Court of the Slovak Republic in case of Marianum-Pohrebníctvo mesta Bratislavy, príspevková organizácia (hereafter, Marianum $)^{18}$, case no. 3Sžh/3/2010

The Supreme Court decided here on an appeal lodged by Marianum against a judgment of the Regional Court in Bratislava.

16 See e.g. the judgment of the Court of Justice of the EU in joined cases C-359/95 P and 379/95 P Commission v Landbroke Racing, ECR [1997] I-6301.

17 OECD policy roundtables: Relationships between Regulators and Competition Authorities, 1998 (available at http://www.oecd.org/dataoecd/30/38/38819635.pdf): 'Competition policy is chiefly ex post (merger review excepted) whereas regulation is primarily ex ante and continuous. When regulation is applied, there will typically be a pre-supposition that market forces cannot be relied on to produce a satisfactory outcome and this cannot be rectified merely by trying to change firms' incentives'.

18 Judgment of the Supreme Court of the Slovak Republic of 3 May 2011, case no. 3/Sžh/3/2010. 
Marianum is an organisation established by the municipality of Bratislava which provides cemetery and funeral services within this city's territory. The Slovak competition authority found in $2008^{19}$ that Marianum was engaged in exclusionary practices by not allowing competing undertakers to provide certain funeral services in the premises of cemeteries and crematories managed by Marianum. Its competitors were excluded from providing services such as religious activities or funeral carrier services. Simultaneously, the dominant company was fund to have directly exploited consumers by imposing upon them unreasonable fees: a fee for the disposal of flower donations after a funeral and a fee charged to new tenants for the disposal of an old gravestone inside the cemetery compound.

It was not possible to subsume such conduct under any of the forms of abuse explicitly listed in the Slovak Act on the Protection of Competition (hereafter, Competition Act). For that reason, the AMO applied in this case the general provisions of the Competition Act that prohibit any abuse, the so called 'general clause'20. The application of the general clause is based on the general idea that competition law is very a dynamic field of law - an explicit enumeration of abuse forms (or, in fact, of the forms of competition restricting agreements) would be unable to cover all the possible variations of unilateral anticompetitive behaviour ${ }^{21}$. The Regional Court in Bratislava rejected the action submitted by Marianum which sought the annulment of the decisions of the AMO but the Supreme Court reversed the first instance judgment.

The use of the general clause was central to the ruling of the Supreme Court which decided that punishing Marianum for breaching the general clause came into conflict with the nullum crimen sine lege rule. The Supreme Court stated that although it was possible to apply the general clause to anticompetitive behaviour, but it was at the same time not possible to impose a punishment for it. According to the Supreme Court, the application of the general clause amounts to the creation of a new form of competition law violation. In other words, when the AMO decides to apply the general clause, it creates, in

19 Decision of the Council of the AMO of 19 December 2008 (no. 2008/DZ/R/2/113) in conjunction with the decision of the AMO of 30 June 2008 (decision no. 2008/DZ/R/2/113).

20 The general clause is set out in Section 8 of the Slovak Act on Protection of Competition concerning the abuse of dominance; it reads: 'Abuse of a dominant position in the relevant market is prohibited'.

${ }^{21}$ See e.g. D. Raus, R. Neruda, Zákon o ochraně hospodářské soutěže, Komentár̆ a souvisicí české i komunitárni predpisy, Praha 2006, p. 174: According to the authors, the construction of the provision prohibiting abuse based on the use of the general clause is indispensable. It is simply not possible to cover all types of anticompetitive behaviour by the strict enumeration of their merits since the insidiousness of such behaviour and complexity of its evaluation increases with time. See also K. Kalesná, O. Blažo, Zákon o ochrane hospodárskej sútaže (komentár), Brno 2012, p. 47. 
essence, the merits of a new infringement. The term "merits" means, in this context, the characteristics of a particular anticompetitive behaviour. The Supreme Court stated that 'the proportionality rule requires that if the AMO is, on the one side, competent to create new merits of the abuse of dominant position on the basis of the general clause then the undertaking has, on the other side, the right to be acquainted with the merits of the anticompetitive behaviour which is forbidden'.

The conclusions of the Supreme Court raise many questions.

The wording of the provisions of the Slovak Competition Act has been constructed in accordance with the text of the Treaty on the functioning of the European Union. Other Member States have constructed their national provisions likewise on the basis of the demonstrative enumeration of prohibited anticompetitive behaviours contained in EU legal system. Truthfully, the general clause does not specify any particular characteristic of anticompetitive behaviours ${ }^{22}$. It simply stipulates that: 'abuse of a dominant position is prohibited'. The general rule can thus be considered at first sight to be a kind of blank norm which makes it possible to punish almost any kind of unilateral behaviour.

It is indisputable that competition law is a comprehensive and complex legal field and that it is often subject to wide-reaching inquiries and assessments by competition authorities. It is also not always clear at the beginning of an investigation whether the scrutinised undertaking actually engaged in a prohibited practice. Still, competition law and policy are largely harmonised among EU Member States and individual NCA usually base their decisions on the jurisprudence of the Court of Justice of the EU and case law of the European Commission. True originality of anticompetitive conduct is therefore rather rare.

This realisation leads to another problem. The Supreme Court associated here the 'originality of the case' with the application of the general clause. It presupposed that when the AMO applied the general clause, it identified a completely new form of anticompetitive behaviour that had never been considered before. However, the correlation between originality and the use of the general clause does not have to be necessarily true and, in fact, did

22 Cp. the Article 11 of the Czech Act no. 143/2001 Coll. of 4 April 2001 on the Protection of Competition and on Amendment to Certain Acts (Act on the Protection of Competition) as amended by Act No. 340/2004 Coll. of 4 May 2004, Act No. 484/2004 Coll. Of 5 August 2004, Act No. 127/2005 Coll. of 22 February, Act No. 361/2005 Coll. of 19 August 2005, Act No. 71/2007 Coll. of 4 April 2007, Act No. 296/2007 Coll. of 1 January 2008 and Act No. 155/2009 Coll. of 1 September 2009.

'(1) Abuse of dominant position to the detriment of other undertakings or consumers shall be prohibited'. 
not exist in the given case. In the Slovak Republic, the need to apply the general clause may arise, for instance, when the merits of an anticompetitive behaviour expressed in the Competition Act simply do not reflect the nature of the scrutinised practice. Such is the case with margin squeeze, for instance, a restrictive practice considered before by many competition authorities, including the European Commission. Margin squeeze is, however, hard to classify as an unfair price practice, a form of abuse explicitly listed both in the Slovak Competition Act and Article 102 TFEU.

The assertion must be supported therefore that when a seemingly new anticompetitive behaviour is under consideration, it is necessary to assess it with reference to its actual originality. It is reasonable, for instance, to significantly reduce the fine imposed in such cases ${ }^{23}$. This approach goes in line with the case law of the European Commission, which has sometimes decided to refrain from the imposition of a fine, if the scrutinised case contained a 'new element' that had not been considered before ${ }^{24}$. This approach takes into account the necessary predictability of the actions of competition authorities ${ }^{25}$.

\section{Bank cartel judgment}

The judgment of the Supreme Court in case of Československá obchodná banka, a.s. (hereafter, CSOB), case no. $5 \mathrm{Sžh} / 4 / 2010^{26}$

The Supreme Court of the Slovak Republic decided here on an appeal submitted by the competition authority against a judgment of the Regional

23 See e.g. the decision of the AMO in case ENVI-PAK.

24 e.g. decision of the Commission no. 93/438/EEC of 30 June 1993 (IV/33.407 - CNSD) or case no. 96/438/EC of 5 June 1996 (IV/34.983 - Fenex). Cf. F. Dethmers, H. Engelen, 'Fines under article 102 of the Treaty on the Functioning of the European Union' (2011) 2 E.C.L.R. 96. Authors criticise therein the fact that companies have only limited success in arguing against (high) fines on such grounds under the per se illegality approach under art. 102 TFEU. According to the authors, there are few cases where no fines were imposed due to the novel nature of the abuse concerned, but such defence is only accepted under exceptional circumstances when there is no precedent to which the case might be compared.

25 Cf. B. Vesterdorf, 'Article 102 TFEU and Sanctions: Appropriate When?' (2011) 11 E.C.L.R. 577. According to the author, Article 102 TFEU is not drafted in clear, precise and unambiguous language and therefore does not create legal certainty. However the author stresses that the lack of clarity of a rule of law may to some extent be remedied by the interpretation of the provision given by the courts. This can only apply to the situation in which the undertaking knew or clearly should have known that such conduct might be unlawful and that the undertaking could not reasonably be in doubt as to its dominant position.

26 Judgment of the Supreme Court of the Slovak Republic of 19 May 2011 (case no. 5 Sžh 4/2010). 
Court in Bratislava, which annulled AMO's decision concerning a cartel of three banks. The decision ${ }^{27}$ issued by the competition authority established the existence and operation of a competition restricting agreement between three banks (including CSOB). The contested practice allegedly consisted of an agreement on the termination and consecutive non-conclusion of new contracts on current accounts with the company AKCENTA CZ, a. s. The competition authority had at its disposal a variety of evidence in this case and based its decision on the existence of a meeting between the parties to the proceedings, e-mails that followed, and their conduct on the market.

The decision of the AMO was annulled by the Regional Court in Bratislava as well as the Supreme Court of the Slovak Republic. The particularity of the judicial review of this case is worth noting. Despite the fact that Slovak law enables the courts to assess in one proceeding all actions lodged against the same administrative decision, the legality of decisions issued by the competition authority in this case was reviewed in three independent proceedings, by both courts, on the basis of three different actions submitted by the parties. In fact, the AMO still awaits a Supreme Court ruling in the case of two banks ${ }^{28}$.

Both courts arrived at the same conclusions during their proceedings namely that AKCENTA did not hold the licence for the performance of business activities on the foreign-exchange market of the Slovak Republic. The courts refused the AMO's objections that the conduct of the plaintiff (as well as of the other banks) should have been seen as anticompetitive irrespective of the fact whether it was directed at an existing or potential market player. As opposed to the competition authority, the courts concluded that the realisation whether the contested practice was directed against an entity that conducted its business in the Slovak territory legally, and thus enjoyed legal protection for its business, was of relevance to the assessment of the anticompetitive nature of the banks' behaviour. In the opinion of the courts, the scrutinised banks had the right to eliminate such an activity. The courts did not accept the objections of the competition authority that the aim of its activities is not to protect particular undertakings but the competition process overall. In the AMO's view, the conclusion cannot be accepted that the banks had the right to eliminate a company which had been operating unlawfully by way of their own anticompetitive behaviour.

The AMO stressed that the National Bank of Slovakia did not issue a decision finding that AKCENTA's operations on the foreign-exchange market were illegal in the period when the agreement was concluded (and AKCENTA's accounts cancelled). The courts replied that the AMO had not

27 Decision of the Council of the AMO no. 209/KH/R/2/054 of 19 November 2009 in conjunction with the decision of the AMO no. 2009/KH/1/1/030 of 9 June 2009.

28 The Regional Court in Bratislava annulled the decision of the AMO in all three cases. 
proven that the said company had in fact operated in the territory of the Slovak Republic legally, that is, that it had indeed held a licence for the performance of the contested activity.

The issue of the illegality of AKCENTA's business operation is especially interesting from the point of view of an anticompetitive object and/or effect. The agreement subject of the decision of the AMO was a multilateral practice which had as its object ${ }^{29}$ the prevention, restriction or distortion of competition. According to the jurisprudence of the Court of Justice of the EU, it is unnecessary to consider the actual effects of an agreement if it is apparent that it has an anticompetitive object ${ }^{30}$. The distinction between infringements by object and infringements by effects arises from the fact that certain forms of collusion can be regarded as being injurious to the proper functioning of normal competition by their very nature ${ }^{31}$. These agreements are prohibited per se, even when they are directed against only a 'potential' market player. Making a distinction between 'legal' and 'illegal' market players would distort the perception of economic reality. Public enforcement of competition law is not intended to protect particular competitors, but the competition process as such.

The question of the illegality of AKCENTA's activities has proven crucial to the remaining proceedings concerning the actions of the rest of the alleged participants of the anticompetitive practice. The Supreme Court of the Slovak Republic has recently brought this question to the Court of Justice of the EU expecting a preliminary ruling to resolve the original case ${ }^{32}$. Interestingly,

29 See R. Whish, Competition law, 5th edition, London 2003, p.110: 'The word 'object' in this context means not the subjective intention of the parties when entering into the agreement, but the objective meaning and purpose of the agreement considered in the economic context in which it is to be applied'.

30 45/85 Verband der Sachversicherer v. European Commission, ECR [1987] 00405, para. 39.

31 C-209/07 Beef industry Development and Barry Brothers, ECR [2008] I-8637, para. 17, See also R. Whish, Competition law, p. 11.: 'The classification of an agreement as having as its object the restriction of competition means that the parties, for example to a price-fixing agreement ,cannot argue that the fixing of prices does not restrict competition: the law has decided, as a matter of policy, that it does...'.

32 Case no C-68/12, Reference for a preliminary ruling from the Najvyšší súd Slovenskej republiky (the Supreme Court of the Slovak Republic), lodged on 10 February 2012 - Slovenská sporitelña, a.s. v Protimonopolný Úrad Slovenskej Republiky (the AMO).

Questions referred:

Is Article 101(1) TFEU (formerly Article 81(1) EC) to be interpreted as meaning that it is of legal relevance that a competitor (trader) adversely affected by a cartel agreement between other competitors (traders) was operating on the relevant market illegally at the time when the cartel agreement was concluded?

For the purposes of interpreting Article 101(1) TFEU (formerly Article 81(1) EC), is it of legal relevance that, at the time when the cartel agreement was concluded, the legality of that 
one of the questions submitted by the Slovak court concerned the relevance of the fact that when the scrutinised practice was concluded, the legality of AKCENTA's activities was not impugned. Awaiting a preliminary ruling, the proceedings before the Slovak Supreme Court are pending ${ }^{33}$.

\section{Infringement of a decision prohibiting a concentration}

The judgment of the Supreme Court in case of Phoenix - medical supply, a.s. (hereafter, Phoenix), case no. 1 Sžhpú 4/200834

In 2005, the Slovak competition authority imposed a fine amounting to c. 1000000 Euro on two undertakings, Phoenix and Biama, for their non-compliance with an earlier decision prohibiting their merger ${ }^{35}$. The AMO considered the conduct of these two undertakings to be a serious offence, and thus imposed such a large fine. Both companies acted on the same relevant market for the wholesale distribution of pharmaceuticals and medical instruments. The merger would have led to the creation of a dominant position on the relevant market.

The Regional Court in Bratislava reviewed the decision of the AMO and by its judgment ${ }^{36}$ substantially reduced the fine (from 1000000 to c. 16600 Euro.) Pursuant to the Court, the fine originally imposed was too repressive. The

competitor's (trader's) conduct was not called in question by the competent supervisory bodies in the Slovak Republic?

Is Article 101(1) TFEU (formerly Article 81(1) EC) to be interpreted as meaning that, in order to find that an agreement is restrictive of competition, it is necessary to demonstrate personal conduct on the part of the representative authorised under the undertaking's constitution or the personal assent, in the form of a mandate, of that representative, who has (or may have) taken part in that agreement, to the conduct of one of the undertaking's employees, where the undertaking has not distanced itself from the conduct of that employee and, at the same time, the agreement has even been implemented?

Is Article 101(3) TFEU (formerly Article 81(3) EC) to be interpreted as also applying to an agreement prohibited under Article 101(1) TFEU (formerly Article 81(1) EC) which by its nature has the effect of excluding from the market a specific individual competitor (trader) which has subsequently been found to have been carrying out foreign currency transactions on the cashless payment transactions market without holding the appropriate licence as required under national law?

${ }^{33}$ See also: M. Nosa, 'Vec AKCENTA CZ, alebo dokazovanie kartelu' (2011) 1 Antitrust 32-37.

34 The judgment of the Supreme Court of the Slovak Republic of 25 January 2011.

35 The decision of the Council of the AMO no. 2005/FH/R/2/090 of 26 August 2005 in conjunction with the decision of the AMO no. 2005/FH/3/1/061 of 20 May 2005.

36 The judgment of the Regional Court in Bratislava of 19 June 2008, case no. 1S 314/2005. 
Court concluded that the fine fulfils both preventive and repressive functions. According to the Court, the authority focused on the latter purpose only.

The Supreme Court did not agree with the conclusions of the Regional Court in Bratislava and upheld the fine originally imposed by the AMO. Its judgment is particularly interesting in terms of the scope of the powers of the court when reviewing administrative decisions. The Regional Court acted in accordance with the provisions of the Civil Procedural Code. Aside from upholding or annulling an administrative decision, the Civil Procedure Code empowers the courts to change the amount of fines imposed in administrative proceedings.

Nevertheless, the Supreme Court of the Slovak Republic stated that a court should not assess the expediency and suitability of an administrative decision. When reviewing it, courts should only examine whether the decision did not go beyond its legal limits, whether it complied with the rules of logical thinking and whether it was based on comprehensive information collected by appropriate procedures. If these conditions are met, courts should not draw from the same circumstances different or contrary conclusions to those of the administrative body.

The Slovak judicial review system of administrative decisions was traditionally based on the cassation principle - courts did not have the power to change administrative decisions; they could only annul them or dismiss the action of the claimant (i.e. uphold the decision of the administrative body). The requirements of Article 6 of the European Convention on Human Rights led to the creation of a new power for the courts when reviewing decisions of administrative bodies, such as the AMO. Since 2002, Slovak courts have thus the right to change the amount of the fine imposed on the parties of administrative proceedings. When reviewing administrative decisions, courts usually base their analysis on facts established by the administrative body. However, they can consider new evidence if necessary in order to review an administrative decision.

This raises questions as to the role of the courts when reviewing administrative decisions. Do they have the power to replace administrative bodies in the fulfilment of their functions?

Taking into consideration all aspects of the administrative justice system, the most satisfactory conclusion to arrive at is that the role of the relevant authorities, such as the AMO, should be preserved. The purpose of judicial review should not replace the functions of administrative bodies. Instead, courts should solely examine if the authorities adhered to the corresponding laws. Since full jurisdiction should be understood in the context of the role of the competition authority has to play, courts should explore new evidence only exceptionally and only if it is of sufficient importance. It is hard to imagine 
the judiciary resolving issues such as relevant market definition ${ }^{37}$, for instance. In such cases, courts should simply ensure that administrative bodies conduct properly the fact-finding process ${ }^{38}$. This opinion complies with the judgment of the Court in the Phoenix case where it was said that courts could not interfere with the discretion of administrative bodies when assessing particular cases.

\section{Conclusions}

It follows from the jurisprudential review above that when it comes to the application of competition rules, Slovak courts often diverge from the European decision-making practice.

Even after 20 years of the functioning of the market economy, competition rules are often viewed as a new element in the Slovak legal order. This may be partly caused by the specific character of competition law, the most important attribute of which is its dynamic character which enables it to cover most anticompetitive market practices. In order to do so, competition law is based on a limited number of sparse written rules that are subject to extensive jurisprudential interpretation. Competition law is also characterised by the increasing use of economic evidence. Both the dynamics and economisation of competition law may conflict the nature of the Slovak legal order which is traditionally based on comprehensive written rules and where jurisprudence is not considered to be a legal source (this conflict was evident, for instance, in the Marianum judgment).

Judgments such as the Railway Company Cargo and the Phoenix Biama case show that it is necessary, above all else, to clarify the relationship between the role of the Slovak competition authority and the role of national courts when assessing competition cases.

It appears also that coherent application of competition law within the EU requires closer cooperation between Slovak courts and the European Commission as well as between national judiciary and the AMO. This

37 This concept resembles the concept of the scope of judicial review of administrative decisions in the EU developed by the jurisprudence of the Court of Justice of the EU. Accordingly, as far as the complex economic assessment of the Commission are concerned, EU courts are confined to verifying if the rules on procedure and on statement of reasons were complied with, whether the facts have been accurately stated and if a manifest error of appraisal or misuse of power occurred (see joined cases C-204/00P, C-205/00P, C-213/00P, C-217/00P and C- 219/00P Aalborg Portland v Commission) in: F.O.W. Vogelaar, The European competition rules, landmark cases of the European Courts and the Commission, $2^{\text {nd }}$ ed., Groningen 2007, p. 341.

38 See also S. Šramelová, T. Britvík, 'Plná jurisdikcia súdov pri preskúmavaní správnych rozhodnutí' (2010) 6-7 Justičná revue 819-827. 
cooperation may be based on informal discussions on contentious issues or on the organization of workshops and training courses in the field of competition law. Whichever way is used, active participation of both Slovak judges and AMO representatives is vital to its success. This may help intensify informal dialogue on the most controversial competition law issues and deepen the understanding of the entire competition law field.

\section{Literature}

Dethmers F., Engelen H., 'Fines under article 102 of the Treaty on the Functioning of the European Union' (2011) 2 E.C.L.R.

Kalesná K., Blažo O., Zákon o ochrane hospodárskej sútaže (komentár) [Act on protection of competition (Commentary)], $1^{\text {st }}$ ed., Brno 2012.

Nosa M., 'Vec AKCENTA CZ, alebo dokazovanie kartelu' ['Case AKCENTA CZ, or on proving a cartel'] (2011) 1 Antitrust.

Raus D., Neruda R., Zákon o ochraně hospodářské soutěže, Komentár a souvisící české $i$ komunitárni predpisy [The act on protection of competition (Commentary) and related Czech and Communitary legal regulations], $2^{\text {nd }}$ ed., Praha 2006.

Šramelová S., Britvík T., 'Plná jurisdikcia súdov pri preskúmavaní správnych rozhodnutî' ['Full jurisdiction in judicial review of administrative decisions'] 2010 (6-7) Justičná revue.

Vesterdorf B., 'Article 102 TFEU and Sanctions: Appropriate When?' (2011) 11 E.C.L.R. Van Bael \& Bellis, Competition law of the European Community, Hague 2005.

Whish R., Competition law, 5th edition, London 2003.

OECD policy roundtables: Relationships between Regulators and Competition authorities 1998; available at http://www.oecd.org/dataoecd/30/38/38819635.pdf. 